University of Nebraska - Lincoln

DigitalCommons@University of Nebraska - Lincoln

November 1992

\title{
Characterization of boron carbide thin films fabricated by plasma enhanced chemical vapor deposition from boranes
}

\author{
Sunwoo Lee \\ Syracuse University \\ John Mazurowski \\ Syracuse University \\ G. Ramseyer \\ General Electric Company \\ Peter A. Dowben \\ University of Nebraska-Lincoln, pdowben@unl.edu
}

Follow this and additional works at: https://digitalcommons.unl.edu/physicsdowben

Part of the Physics Commons

Lee, Sunwoo; Mazurowski, John; Ramseyer, G. ; and Dowben, Peter A., "Characterization of boron carbide thin films fabricated by plasma enhanced chemical vapor deposition from boranes" (1992). Peter Dowben Publications. 157.

https://digitalcommons.unl.edu/physicsdowben/157

This Article is brought to you for free and open access by the Research Papers in Physics and Astronomy at DigitalCommons@University of Nebraska - Lincoln. It has been accepted for inclusion in Peter Dowben Publications by an authorized administrator of DigitalCommons@University of Nebraska - Lincoln. 


\title{
Characterization of boron carbide thin films fabricated by plasma enhanced chemical vapor deposition from boranes
}

\author{
Sunwoo Lee \\ Department of Physics and Solid State Science \& Technology Program, Syracuse University, Syracuse, \\ New York 13244-1130 \\ John Mazurowski \\ Department of Physics, Syracuse University, Syracuse, New York 13244-1130 and General Electric \\ Company, Electronics Laboratory, Electronics Park, Syracuse, New York 13221 \\ G. Ramseyer ${ }^{\text {a) }}$ \\ General Electric Company, Electronics Laboratory, Electronics Park, Syracuse, New York 13221 \\ P. A. Dowben ${ }^{\text {b) }}$ \\ Department of Physics and Solid State Science \& Technology Program, Syracuse University, Syracuse, \\ New York 13244-1130
}

(Received 22 May 1992; accepted for publication 22 July 1992)

We have fabricated boron carbide thin films on $\mathrm{Si}(111)$ and other substrates by plasma-enhanced chemical-vapor deposition (PECVD). The PECVD of boron carbides from nido-cage boranes, specially nido-pentaborane $(9)\left(\mathrm{B}_{5} \mathrm{H}_{9}\right)$, and methane $\left(\mathrm{CH}_{4}\right)$ is demonstrated. The band gap is closely correlated with the boron to carbon ratio and can range from 0.77 to $1.80 \mathrm{eV}$ and is consistent with the thermal activation barrier of $1.25 \mathrm{eV}$ for conductivity. We have made boron carbide by PECVD from pentaborane and methane that is sufficiently isotropic to obtain resistivities as large as $10^{10} \Omega \mathrm{cm}$ at room temperature. This material is also shown to be suitable for photoactive $p-n$ heterojunction diode fabrication in combination with $\mathrm{Si}(111)$.

\section{INTRODUCTION}

A wide variety of techniques have been employed to make boron-rich carbides. ${ }^{1-31}$ Most of these techniques result in boron carbides with only a limited range of compositions as summarized in Fig. 1. Employing alkanes and heavy borane cage molecules, as noted in preliminary papers, ${ }^{6-8}$ is a relatively safe and effective alternative for fabricating boron carbide thin films. The use of plasmaenhanced chemical-vapor deposition (PECVD) provides a means for fabricating boron carbide thin films without resorting to high temperatures $\left(>1000{ }^{\circ} \mathrm{C}\right)$ and pressures $(>50$ Torr) that have been required to fabricate boron carbides. ${ }^{3,9-14,16-18,29,32}$ Typical CVD deposition experiments have employed $\mathbf{B C l}_{3}$ and hydrocarbons such as methane, ${ }^{17,18,22,24-26} \mathrm{BCl}_{3}+\mathrm{CCl}_{4},{ }^{11,15,27,31} \mathrm{BBr}_{3}$ and methane $\mathrm{e}^{3,16,18,20,23,32,33}$ or $\mathrm{BI}_{3}$ and methane. ${ }^{3}$ We have previously shown that nido-decaborane (14) $\left(\mathrm{B}_{10} \mathrm{H}_{14}\right)$ was a suitable source for the deposition of boron, ${ }^{6}$ boron carbide, ${ }^{7}$ boron nitride films, ${ }^{6}$ and is now widely used for the boron doping of silicon. ${ }^{34-37}$ Lighter boranes like diborane $\left(\mathrm{B}_{2} \mathrm{H}_{6}\right)$ have been explored ${ }^{4,38-40}$ but are extremely hazardous resulting in the search for safer boron source alternatives such as borontrioxide $\left(\mathrm{B}_{2} \mathrm{O}_{3}\right){ }^{5}$ Boron carbide films have also been made by sputtering boron carbide targets. ${ }^{1,2} \mathrm{~A}$ few examples of boron carbide from carboranes do exist ${ }^{8,13,19}$ but are limited in scope.

The work undertaken to assess the properties of boron carbides has been controversial despite the considerable

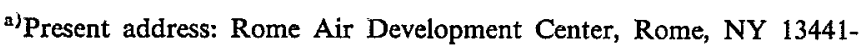
5700.

b) Address correspondence to this author.
}

efforts to theoretically model $\mathrm{l}^{41-54}$ and fabricate these materials. ${ }^{1-5,9-31}$ In this paper, we provide some indication of the electronic structure and optical properties of boron carbides fabricated by PECVD.

\section{EXPERIMENT}

\section{A. Film fabrication}

Nido-decaborane(14) and nido-pentaborane(9) were used as source compounds with methane. Nidodecaborane(14) was an air-stable white crystalline solid with a vapor pressure of several Torr at room temperature and obtained from the U.S. Army at Redstone Arsenal, vacuum sublimed and stored in vacuo prior to use. Nidopentaborane(9) was from our laboratory stock. The identity and purity of compounds were determined by nuclear magnetic resonance (NMR), Fourier transform infrared spectroscopy (FTIR), and mass spectral measurements. The sample cell was heated to increase the vapor pressure of nido-decaborane (14) (the vapor pressure was 19 Torr at $100^{\circ} \mathrm{C}$ ) for the experiments with $\mathrm{B}_{10} \mathrm{H}_{14}$. Deposition of the films was performed in a custom designed parallel plate $13.56 \mathrm{MHz}$ radio-frequency PECVD reactor described previously. ${ }^{7}$ Various composition of boron carbide films were grown on $n$-type $\mathrm{Si}(111)$ and high-temperature glass (Dow-Corning 7059 glass) by adjusting the partial pressure ratio of two reactants. No carrier gas was used for these experiments. $\mathrm{Si}(111)$ and glass were chemically etched and cleaned prior to insertion in vacuo and set on the lower electrode. The substrates were further cleaned by $\mathrm{Ar}^{+}$bombardment at $100 \mathrm{mTorr}, 20 \mathrm{~W}$ and annealed at $400{ }^{\circ} \mathrm{C}$ in the vacuum system. The growth temperature of 


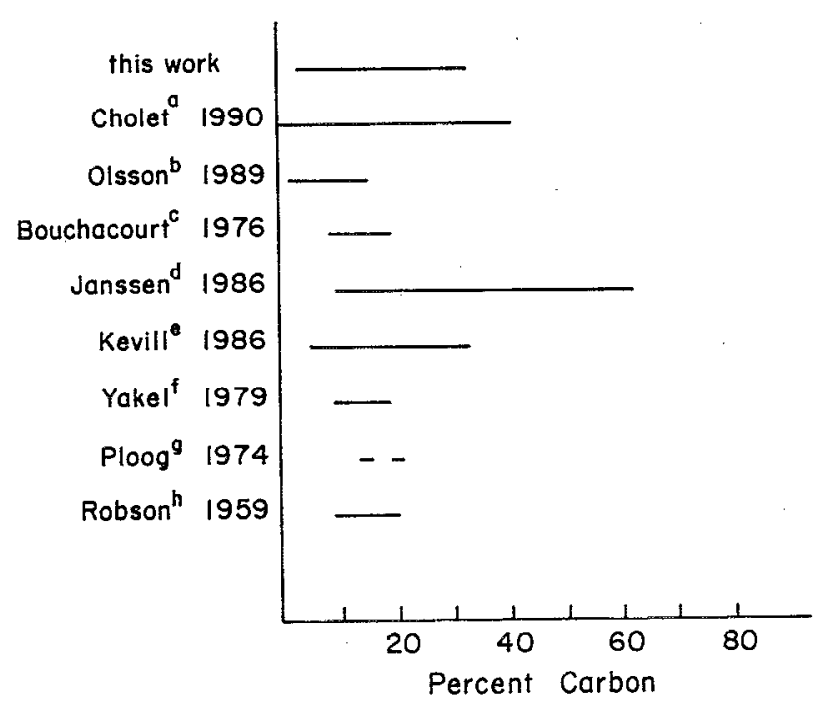

FIG. 1. Schematic comparison of various selected experimental deposition studies of boron carbide compositions: (a) Ref. 16, (b) Refs. 17 and 24, (c) Refs. 19 and 29, (d) Ref. 24, (e) Ref. 27, (f) Ref. 28, (g) Ref. 20, (h) Ref. 30, and this work.

thin film, total pressure of reactants, applied power, and deposition time were fixed for the entire experiment, approximately $400^{\circ} \mathrm{C}, 50 \mathrm{mTorr}, 20 \mathrm{~W}$ (maximum power density of $3.7 \mathrm{~W} / \mathrm{cm}^{2}$ ) and $30 \mathrm{~min}$, respectively.

\section{B. Film characterization}

The compositions of thin films were determined by a Perkin Elmer Auger electron spectrometer equipped with a cylindrical mirror analyzer (CMA). The system was calibrated using the boron $179 \mathrm{eV}$ line and the carbon $272 \mathrm{eV}$ line of a $\mathrm{B}_{4} \mathrm{C}$ standard combined with $\mathrm{Ar}^{+}$ion sputtering to provide a depth profile of the composition. The thicknesses of the films were from 0.1 to $1.0 \mu \mathrm{m}$ thick depending upon reactants and their partial pressure ratios. Auger profiling was limited by a mask to a $2 \mathrm{~mm}$ square to reduce the thickness measurement error. The depth of this sputtered square was measured using a Sloan Dektak profilometer. Auger profile data was then calibrated to this measured depth.

The optical absorption spectra of the different composition films on the glass produced from nidopentaborane(9) were recorded with a double monochromator Cary Model 14 UV-Vis-IR spectrophotometer. The band-gap energies of the films on glass were determined by the standard Tauc plot. ${ }^{55}$ Photoluminescence spcctroscopy was employed using a $-1 \mathrm{~m}$ double grating spectrometer both at room temperature and low temperature (4-12 K). The excitation energy was provided by a $200 \mathrm{~mW} 514.5 \mathrm{~nm}$ $\mathrm{He}-\mathrm{Ne}$ laser for the room-temperature photoluminescence spectrum. The low-temperature $(4-12 \mathrm{~K})$ photoluminescence spectrum was obtained on samples immersed in liquid helium and excited with $15 \mathrm{~mW} 632.8 \mathrm{~nm} \mathrm{He}-\mathrm{Ne}$ laser. Co-planar chromium contacts were evaporated on boron carbide thin films on glass substrates for the dark electrical conductivity measurements. The conductivity was measured using two and four probes from room temperature to about $100^{\circ} \mathrm{C}$.

For the $p-n$ heterojunction diode fabrication, $\mathrm{B}_{4.7} \mathrm{C}$ (composition of the boron carbide) films with thicknesses from 1 to $0.1 \mu \mathrm{m}$, which corresponded to band gaps of 0.8 $\mathrm{eV}$, were grown on $n$-type $\mathrm{Si}(111)$. Silver contacts were made on samples to test the diodes. To characterize the properties of the diodes, $I-V$ characteristic curves were obtained with a Tektronix Type 575 Transistor-Curve Tracer.

$\mathrm{X}$-ray diffraction experiments were performed using a Phillips model PW1729 diffractometer using copper $K \alpha$ radiation and a General Electric model XRD5 diffractometer also using copper $K \alpha$. Specimens were scanned through $2 \theta$ angles ranging from $10^{\circ}$ to $100^{\circ}$.

\section{RESULTS AND DISCUSSION}

\section{A. Film composition and structure}

Two borane sources have been used to make boron carbide films: nido-decaborane(14), $\mathrm{B}_{10} \mathrm{H}_{14}$ and nidopentaborane (9), $\mathrm{B}_{5} \mathrm{H}_{9}$. For each deposition, the correct partial pressures for each source mixture were attained and stabilized. A plasma was then struck and held for the duration of the film deposition. Using this procedure, and provided that the source compounds were pure (contained little admixture of contaminants), it was relatively easy to fabricate pure boron carbide films.

Some oxygen was found upon exposing the films to air, particularly for the films fabricated from nidodecaborane(14). In general, the films fabricated using nido-decaborane(14) as the boron source material were found to be less compositionally uniform than films fabricated from nido-pentaborane(9). Because the film stoichiometry and compositional uniformity could be more easy to control using nido-pentaborane(9) than with nidodecaborane(14), this paper largely reflects films made with nido-pentaborane(9).

Figure 2 shows an Auger electron spectra for a typical film. Little or no impurities were observed upon analysis of the Auger electron spectra for films deposited from pentaborane and methane. By sputtering the films at a fixed rate, film composition profiles were generated. A typical elemental composition profile is shown in Fig. 2 for a boron carbide film deposited on $\mathrm{Si}(111)$. Hydrogen is the only impurity in the source gases but elemental analysis of very thick films indicates the hydrogen impurity level is much less than $6 \%{ }^{6}$

Defining the partial pressure ratio as the ratio of partial pressures for the source vapor pentaborane containing boron and the source vapor methane containing carbon, we find a correlation between partial pressure ratio and the boron to carbon ratio for the resulting film, as shown in Fig. 3. Systematic errors occur as a result of sample annealing temperature, plasma power and total pressure that are not fully understood but for a single set of parameter conditions the correlation between partial pressures and film composition can be easily identified (as seen in the 




FIG. 2. An Auger electron spectroscopy depth profile of boron, carbon, oxygen and silicon of a boron carbide film fabricated from nidopentaborane(9) and methane deposited in a $20 \mathrm{~W}$ of plasma reactor on $\mathrm{Si}(111)$. Atomic percent composition is plotted against $\mathrm{Ar}^{+}$ion sputtering time. Auger electron spectra of boron carbide fabricated from 44 mTorr of $\mathrm{CH}_{4}$ and $6 \mathrm{mTorr}$ of $\mathrm{B}_{5} \mathrm{H}_{9}$ in a $20 \mathrm{~W}$ rf plasma is shown in the inset.

insert to Fig. 3). The relationship is not a proportional relationship even when available boron or carbon atom numbers are considered. Extreme partial pressure ratios produce only moderate film composition ratios. For instance, a drastic reduction in the pentaborane source partial pressure produces only a moderate decrease in measured boron percent in the film. Likewise, a drastic increase in pentaborane source partial pressures produces a moderate increase in measured boron percent for the very boron rich films. Large differences in the boron to carbon content in the film are still attainable and compared well with bo-

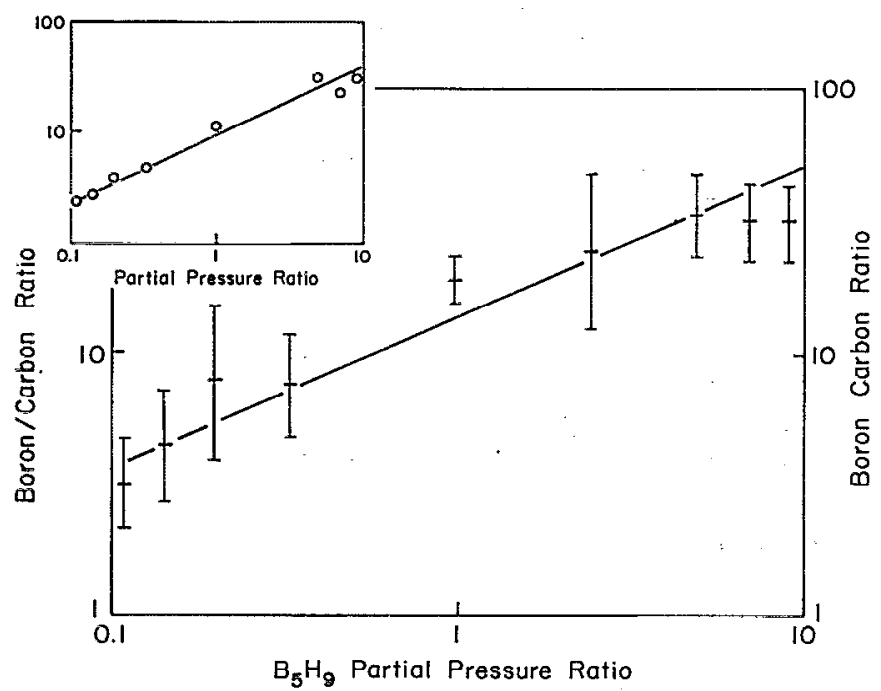

FIG. 3. Boron to carbon ratios determined by Auger electron spectroscopy plotted against the ratio of nido-pentaborane(9) to methane partial pressures. The correlation is shown for one specific plasma reactor geometry and fixed conditions in the insert showing that errors are essentially systematic.



FIG. 4. Broad peak of diffraction pattern for $\mathrm{B}_{7.2} \mathrm{C}$ on $\mathrm{Si}(111)$ is shown in the $2 \theta$ range from $20^{\circ}$ to $60^{\circ}$. Large sharp peaks are identified as $\mathrm{Si}\langle 111\rangle, \mathrm{Si}\langle 222\rangle$, respectively, as indicated at bottom. Boron carbide features are emphasized at top.

ron carbide films made by other methods as seen in Fig. 1. Pure boron or carbon films could, of course, be produced by using only borane or hydrocarbon sources, respectively.

The lack of proportionality in controlling film composition by relative partial pressure changes suggest that many surface reactions may occur including carborane cluster formation initiated during the deposition process or gas phase plasma initiated chemistry. Adsorption studies of simple carboranes on boron carbide films and on $\mathrm{Si}(111)$ indicates that the decomposition process of a carborane can be very complex. ${ }^{8,56}$ For the adsorption and dissociation of nido-diethyl-2,3-dicárbahexaborane on $\mathrm{Si}(111)$ (Ref. 56) and on boron rich surfaces, ${ }^{8}$ the formation of boron rich surface complexes prior to dissociation can be clearly observed even for film deposition and molecular dissociation initiated by incident radiation. ${ }^{8}$ It is difficult to exclude the possibility that plasma mediated gaseous species affect the relationship between partial pressure and film composition. It is well known that pentaborane and hexaborane species are a thermodynamic sink in the thermolysis and photolysis of light boranes. ${ }^{57}$ Other similar thermodynamic carborane sinks also may exist. The results obtained with PECVD of boron carbide using the lighter boranes ${ }^{39}$ indicates that our results may be applicable to PECVD fabrication with many boranes and carboranes.

X-ray diffraction studies of thicker films of boron carbide ( $>1 \mu \mathrm{m}$ ) deposited on $\mathrm{Si}(111)$ do exhibit boron carbide diffraction features as seen in Fig. 4. The diffraction lines are broad in the range $42^{\circ} \leqslant 2 \theta \leqslant 50^{\circ}$. Calculated $d$ spacing values corresponding to the doublet broad peaks are 2.03 and $1.87 \AA$. The isotropic boron carbide phase produced by PECVD may be easily distinguished from silicon substrate. The $d$-spacing values are smaller than the reported value $\left(2.74 \AA\right.$ ) for single crystalline $B_{7} C{ }^{39,58}$ but are very close to the nearest neighbor bond lengths expected for this material. The films do exhibit diffraction patterns more characteristic of microcrystalline or amorphous films than crystalline boron carbide. Boron-rich materials, particularly from the $\alpha$-rhombohedral polytype, are 


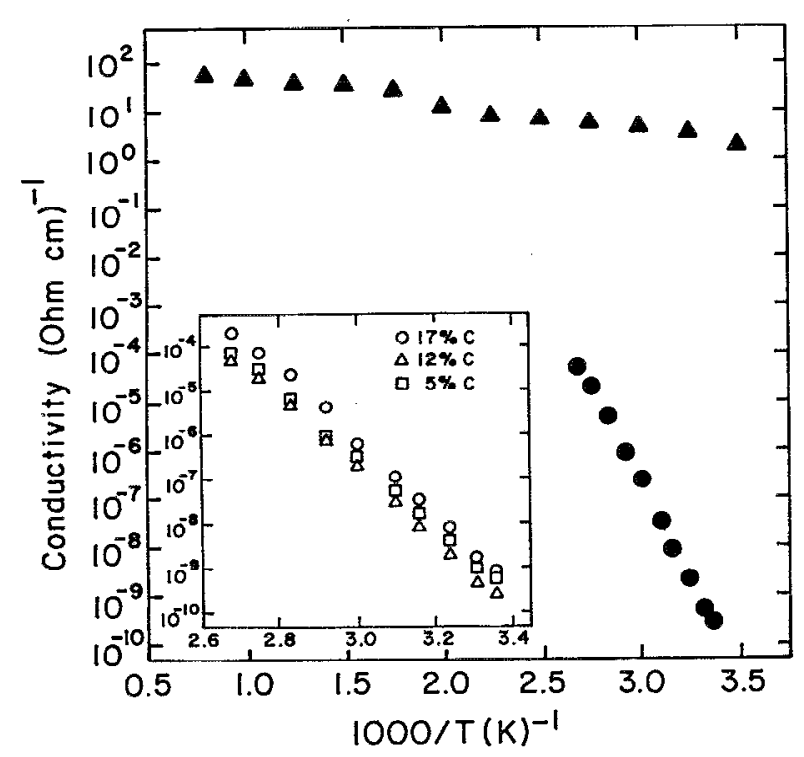

FIG. 5. Conductivities vs reciprocal temperature of approximately $20 \%$ carbon containing boron carbide samples using different fabrication techniques are compared. $(\Delta)$ is taken from Wood and Emin (Ref. 32) and (O) is this work. The conductivities for PECVD fabricated films of different compositions are shown at the insert, indicating that the conductivity is largely independent of carbon concentration.

regarded as natural structural models for amorphous semiconductors. ${ }^{59-62}$ This may be more true of our films than perhaps boron carbides fabricated by other means, though the diffraction results are suggestive of at least some shortrange order (not a truly amorphous material).

Despite the absence of evidence for long-range crystallographic order in our boron carbide thin films, heterojunction diodes can be fabricated by depositing boron carbides by $\mathrm{PECVD}$ on $\mathrm{Si}(111)$. This requires surface preparation of the $\mathrm{Si}(111)$ surface. An increase in carriers in the boron carbide films is clearly indicated from conductivity and diode characterization for films deposited on inadequately prepared substrates. While by no means conclusive, this does suggest that morphology and substrate initiated defects can alter the electrical properties of boron carbides, as discussed below.

\section{B. Conductivity}

The dark electrical conductivity was measured for boron carbide films that spanned a composition range from 4.7 to 19.0 boron to carbon ratio, for temperatures from room temperature to $100^{\circ} \mathrm{C}$. The electrical conductivity is seen to vary exponentially with reciprocal temperature, as seen in Fig. 5. As seen in the insert to Fig. 5, there is little variation in the conductivity as a function of composition. While the conductivities in this composition range are observed to be very small $\sim 10^{-4}$ to $\sim 10^{-10} \Omega^{-1} \mathrm{~cm}^{-1}$, illuminating the samples with visible light is not seen to dramatically affect the conductivity (changes by more than a factor of 4 have not been observed), and we conclude that the conductivity is generally insensitive to visible light.
The conductivity of boron carbides has been previously studied by Emin and co-workers, ${ }^{32,63-67}$ Zuppiroli and coworkers, ${ }^{61,68-69}$ and others. ${ }^{70-82}$ As with rhombohedral boron $^{83,84}$ the primary mode of conduction is generally thought to be by hopping. ${ }^{32,61,65,67}$ It has been reported that the magnitude of the electrical conductivity varies considerably with sample preparation and material purity. While our conductivity is much smaller than reported for boron carbide samples, it has been noted that free carbon will dramatically enhance the dc conductivity. ${ }^{68}$ Thus, our conductivity measurements suggest that in spite of the large carbon concentrations in our PECVD fabricated films there is little free carbon. This evidence for more uniform isotropic films is also supported by the thermal activation barrier. Indeed, the magnitude of our conductivities is seen for other boron carbides only at temperatures well below room temperature. ${ }^{66-69,78}$

The calculated thermal activation barrier for our PECVD fabricated boron films is $1.25 \mathrm{eV}$ and is virtually independent of composition. While Emin and co-workers observe conductivities that are weakly dependent on composition, ${ }^{32,65,67}$ their conductivities are much higher (as plotted in Fig. 5) and their thermal activation barriers are much smaller $(0.14 \pm 0.01 \mathrm{eV}) \cdot{ }^{32,67}$ Werheit and de Groot also find little dependence of the composition on conductivity and observe a thermal activation energy that is also very small $(0.16 \mathrm{eV}){ }^{72}$ The activation barriers measured by Wood, ${ }^{77}$ and Zuppiroli and co-workers ${ }^{61,68}$ are somewhat larger with values of $0.3-0.4 \mathrm{eV}$ and conductivities only weakly depend upon coverage. The magnitude of our thermal conductivity activation barrier is much closer to that of pure boron as measured by Morita and Yamamoto $(0.51-0.58 \mathrm{eV}),{ }^{85} \mathrm{Neft}$ and Seiler $(0.42 \mathrm{eV}),{ }^{86}$ Niemyski and Zawadzki (1.05-1.16 eV) (Ref. 87) and others (1.35$1.45 \mathrm{eV}$ ) (Refs. 86 and 88-97). The conductivities of PECVD fabricated boron carbide, for the most part, also are consistent with the magnitude of the conductivities measured for pure boron. Thus, the conductivity suggests that even for our most carbon rich films, there is little or no free carbon unlike other boron carbides. For the boron rich boron carbides, our PECVD fabricated boron carbide is more easily reconciled with the results obtained for pure boron than boron carbides fabricated by other methodologies.

\section{The band gap}

Over the composition range from 2.4 to 50 boron to carbon ratio the optical band-edge absorption was measured for different boron carbide composition. The optical band gap was obtained from this data as shown in Fig. 6, as is the accepted practice. ${ }^{55,98}$ For the highest carbon concentration, the lowest bad gap $(0.77 \mathrm{eV})$ was obtained and the band gap could be varied from 0.77 to $1.80 \mathrm{eV}$. The band gap is seen to be a closely related property of composition of our boron carbide films as seen in Fig. 7. The band gap for boron-rich films obtained by us is in good agreement with the band gaps determined by Klein (1.5$1.6 \mathrm{eV}$ ) (Ref. 99) and Horn (1.6-2.0 eV) (Ref. 97) and are somewhat larger than the band gap estimated by others 


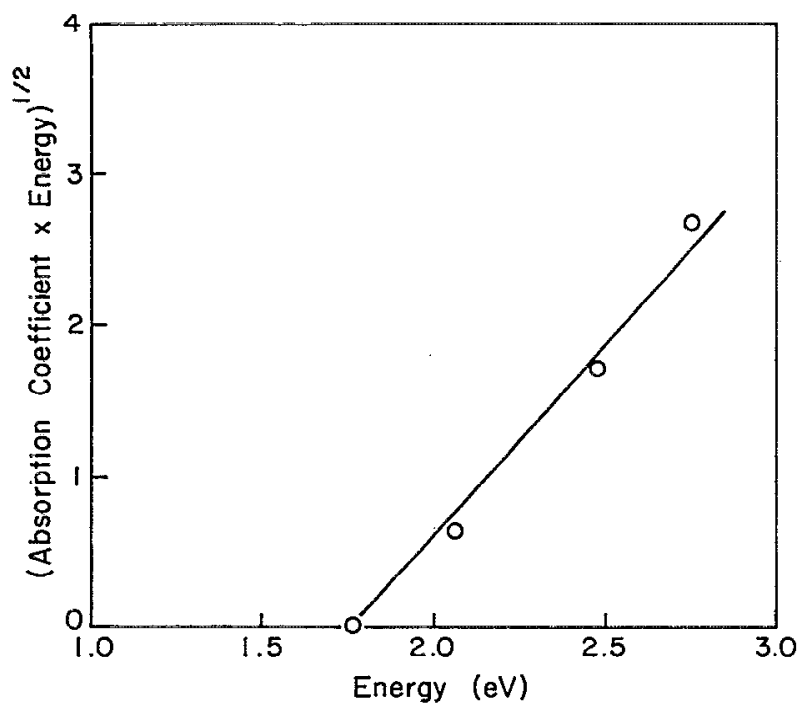

FIG. 6. Optical absorption spectrum for a boron carbide film of approximately $2 \%$ carbon. Extrapolated line to energy axis shows the value of band gap.

$(1.34 \mathrm{eV}) .^{98}$ The absorption edge derived band gap is seen to be consistent with the band gap obtained from photoluminescence spectra. Photoluminescence spectrum exhibits a peak at $1.76 \mathrm{eV}$ (Fig. 8) for $\mathrm{B}_{50} \mathrm{C}$, is consistent with an absorption edge derived band gap of $1.77 \mathrm{eV}$.

Comparison of these measured band gaps at room temperature with theory (Table I) shows that our band gaps, in general, are smaller than expected. To reconcile the band gap we measure with the calculated indirect band gaps, one notes that band gaps calculated by density functional theory are often wrong for zinc blende and diamond structure semiconductors. We, thus, can reconcile the calculated results of Kleinman and co-workers ${ }^{44,50}$ to our experimental results. It is also important to note that there exist two icosahedral boron carbide structures. The one

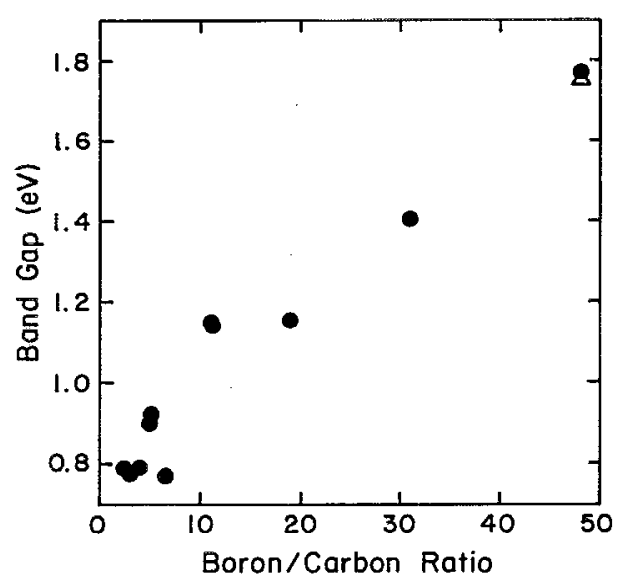

FIG. 7. Band gaps determined at room temperature are plotted against composition determined by Auger electron spectroscopy. The measurement $(\odot)$ are largely determined by optical absorption but data $(\Delta)$ for photoluminescence is also shown.

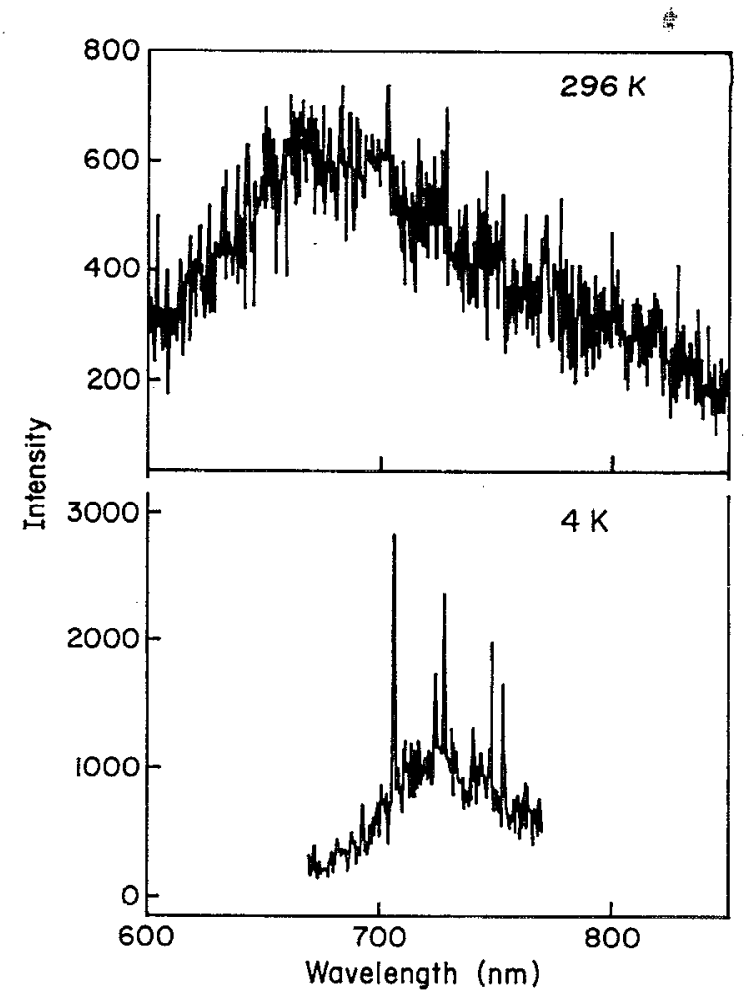

FIG. 8. Photoluminescence spectrum taken at $300 \mathrm{~K}$ is shown at top for $\mathrm{B}_{50} \mathrm{C}$ boron carbide while the photoluminescence spectrum taken at $4 \mathrm{~K}$ is shown at bottom.

fabricated in PECVD may have a somewhat different structure that the one commonly fabricated. ${ }^{44,50}$ This may account for some of the differences in conductivity and band gap from other bulk boron carbides.

TABLE I. Comparison of various boron and boron carbide film band gaps. Parentheses indicate an estimated value, not direct measurement.

\begin{tabular}{|c|c|c|c|c|}
\hline \multirow[b]{2}{*}{ Composition } & \multicolumn{2}{|c|}{ Band gap (eV) (theory) } & \multicolumn{2}{|c|}{ Band gap $(\mathrm{eV})$ (experiment) } \\
\hline & Direct & Indirect $\cdots$ & Direct & Indirect \\
\hline \multirow[t]{2}{*}{$\mathrm{B}_{12} \mathrm{C}_{3}$} & $3.05^{b}$ & $2.80^{b}$ & $\cdots$ & $\cdots$ \\
\hline & $2.03^{\circ}$ & $1.70^{\mathrm{c}}$ & $\cdots$ & $\cdots$ \\
\hline \multirow[t]{2}{*}{$B_{12}$} & $1.78^{\mathrm{d}, \mathrm{e}}$ & $1.43^{\mathrm{d}, \mathrm{e}}$ & $\cdots$ & $\cdots$ \\
\hline & $2.17^{f}$ & $1.70^{\mathrm{f}}$ & $\cdots$ & $\cdots$ \\
\hline \multirow[t]{3}{*}{$\mathbf{B}_{50}$} & $2.16^{\mathrm{f}}$ & $\cdots$ & $\cdots$ & $\cdots$ \\
\hline & $\cdots$ & $\cdots$ & $\cdots$ & $1.4-2.1^{\mathrm{g}}$ \\
\hline & $\cdots$ & $\cdots$ & $\cdots$ & $1.54^{\mathrm{h}}$ \\
\hline \multirow[t]{3}{*}{ Pure boron } & $\cdots$ & $\cdots$ & $\cdots$ & $1.6-2.0^{\mathrm{i}}$ \\
\hline & $\cdots$ & $\cdots$ & $\ldots$ & $1.34^{\mathrm{j}}$ \\
\hline & $\cdots$ & $\ldots$ & .. & $1.5-1.6^{k}$ \\
\hline \multirow[t]{2}{*}{$\mathrm{B}_{50} \mathrm{C}$} & $\cdots$ & ... & $(2.1 \pm 0.2)^{a}$ & $1.76 \sim 1.80^{a}$ \\
\hline & $\cdots$ & $\cdots$ & $\ldots$ & $1.60^{\prime}$ \\
\hline \multirow[t]{2}{*}{$\mathrm{B}_{9} \mathrm{C}$} & $\cdots$ & $\cdots$ & $\cdots$ & $1.00^{\mathrm{a}}$ \\
\hline & $\cdots$ & $\cdots$ & $\cdots$ & $0.7-0.8 \mathrm{~m}$ \\
\hline
\end{tabular}

${ }^{a}$ This work.

bee Ref. 45.

'See Ref. 43.

'See Ref. 44.

'See Ref. 50.

See Ref. 41.

${ }^{8}$ See Ref. 40.
hSee Ref. 103.

iSee Refs. 82, 97, and 104. 'See Ref. 98.

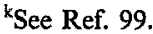

See Ref. 100.

"mee Ref. 77. 


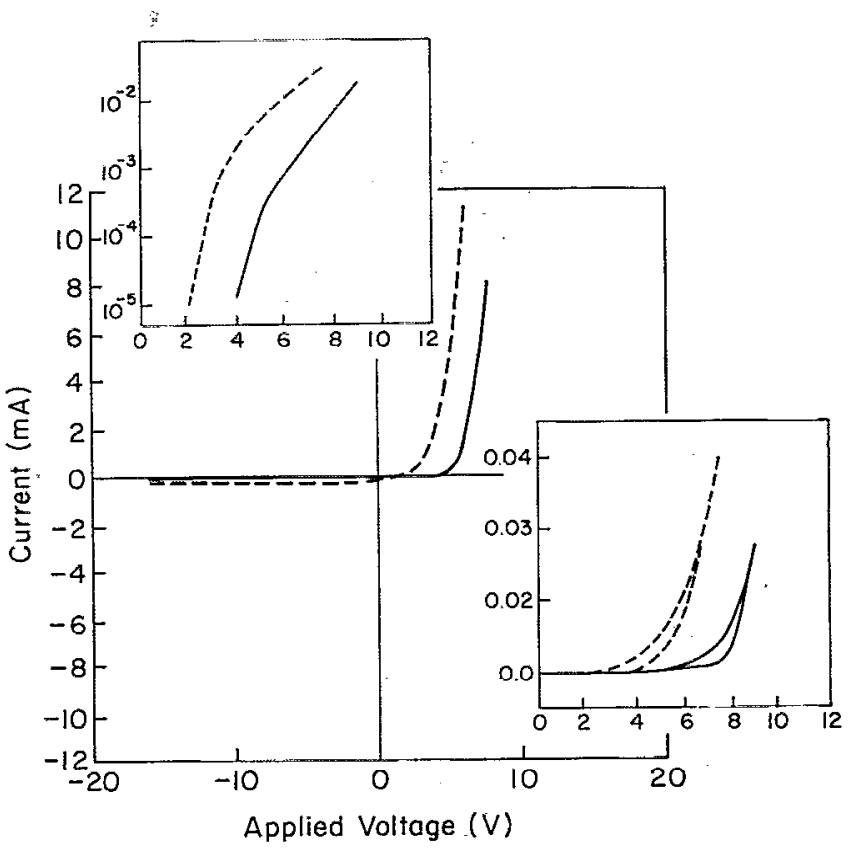

FIG. 9. $I-V$ characteristic curves of $\mathrm{B}_{4.7} \mathrm{C} / \mathrm{Si}(111) p-n$ heterojunction diode. $I-V$ curves were obtained for illuminated $(-)$ and dark $(-)$ samples indicating the light sensitivity of these diodes. Forward bias current plotted in log scale shows that the current does not increase exponentially (left-top inset). Curves plotted on an expanded scale clearly show hysteresis (right-bottom inset).

On the other hand, the band gap we determine for our PECVD fabricated samples shows a greater dependence upon composition than is indicated by some measurements, ${ }^{100}$ resulting in much smaller band gaps than expected $(<1 \mathrm{eV}$ as opposed to $1.6 \mathrm{eV})$ as the carbon concentration increases. The results of Werheit ${ }^{101,102}$ are reasonably consistent with our measurements.

Low-temperature photoluminescence data for the boron rich $\mathrm{B}_{50} \mathrm{C}$ samples shows sharp features at $1.71,1.70$, 1.65 , and $1.64 \mathrm{eV}$ for spectra taken at 4 to $12 \mathrm{~K}$. Such sharp features can be either a consequence of exitonic formation or shallow trapping levels. If we assume that these features are a consequence of shallow trapping levels, we can use the estimate by Nadolny ${ }^{49}$ of 0.34 and $0.45 \mathrm{eV}$ for the depth of the shallow trapping levels to postulate that the "directlike" band gap is close to $2.1 \pm 0.2 \mathrm{eV}$ for the boron rich $\mathrm{B}_{50} \mathrm{C}$ PECVD boron carbide. Similar results can be obtained using the measured $0.18,0.37,0.58$, and 0.77 $\mathrm{eV}$ shallow trapping levels below the conduction band edge obtained by Franz and Werheit. ${ }^{60,101,103,104}$ Suppression of the $1.76 \mathrm{eV}$ broad photoluminescence band upon cooling the sample to $4 \mathrm{~K}$ indicates that this is an indirect not direct transition.

\section{Charge depletion and boron carbide/Si(111) heterojunction diodes}

Since we have ascertained that boron carbide made by PECVD has a large band gap, we have tested the postulate that boron carbide has few carriers (as indicated by the low conductivity and other measurements) by fabricating



FIG. 10. Threshold or onset voltage for forward biased current flow of mesa geometry $p-n$ boron carbide/Si(111) heterojunction diodes as a function of boron carbide film thickness. The figure shows the qualitative differences between illuminated (-O-) and dark (-) samples as a function of $\mathbf{B}_{4.7} \mathbf{C}$ film thickness.

heterojunction diodes with $\mathrm{Si}(111)$. As seen in Fig. 9, boron carbide makes an excellent $p-n$ diode with $n$-type silicon doped to a $7 \times 10^{14} / \mathrm{cm}^{3}$ (moderate) doping level. This is not surprising since boron carbide is generally considered as a $p$-type material ${ }^{61}$ and boron is a common $p$-type dopant of silicon. ${ }^{8,34-37,105}$

The absence of an exponential increase in current versus applied forward voltage (as seen in the insert to Fig. 9) is consistent with a high resistivity material. The hysteresis that appears in the $I-V$ traces, shown in Fig. 9, has also been observed for other heterojunction diodes ( $\mathrm{ZnSe} /$ $\mathrm{ZnCdSe}$ ) and has been interpreted as an effective resistor in series with a diode. ${ }^{106}$ Both the hysteresis of the $I-V$ curve and the deviation from exponential behavior are indicative of the high resistivity of boron carbide. Other similar high resistivity diodes have becn fabricated out of unconventional materials such as diamond. ${ }^{107}$

Unlike the pure boron carbide material, the heterojunction is seen to be strongly photoactive. Visible light is seen to increase the current in both the forward and reverse bias directions, but the effect of light is most pronounced in the forward direction, as seen in Fig. 9. This is consistent with the formation of a space-charge bilayer at the $\mathrm{B}_{4.7} \mathrm{C} /$ $\mathrm{Si}(111)$ interface. Given the very low conductivity of boron carbide, we would anticipate that the depletion layer would be quite large. Using the threshold of forward current flow in the analog $I-V$ plot as a figure of merit, we have determined that increasing the boron carbide film thickness of $\mathrm{B}_{4.7} \mathrm{C}$ has a dramatic effect on the heterojunction $I-V$ characteristics as seen in Fig. 10. This is consistent with the low carrier concentration in boron carbide.

From the thickness dependence, we can estimate space-charge depletion/enrichment extends into the boron carbide layer more than $1 \mu \mathrm{m}$. Si(111) more highly doped. 
(by a factor of 10) than used to fabricate these heterojunction diodes is seen to have space charge layers that extend more than $0.1 \mu \mathrm{m}$ from an interface. ${ }^{108}$ Given the low carrier concentration anticipated for boron carbide, our results are not surprising.

\section{CONCLUSION}

Boron carbide fabricated by PECVD exhibits vastly reduced conductivities over boron carbide fabricated by other methods. We find that increasing carbon concentration reduces the band gap consistent with models proposed by Werheit and co-workers ${ }^{101,102}$ and the band gap can be correlated with composition.

The lower conductivities may be a consequence of the reduction of free carbon as may occur with other fabrication techniques. ${ }^{9,68}$ Graphitic carbon precipitates accounting for much as $2 \%$ to $3 \%$ of the material may not be detectable ${ }^{68}$ but could lead to drastically enhanced conductivities particularly at grain boundaries. Given the lack of information of the various microstructures, the differences between PECVD boron carbide and other boron carbides cannot be unequivocally determined. Heterogeneous distribution of composition is indicated for the crystalline boron carbides by some studies, ${ }^{9,58,68,109}$ but not all. ${ }^{10}$

The films made by PECVD of borane, by virtue of their low carrier concentration, uniformity and readily formed space-charge layers (adjustable by either changing film thickness or boron carbide composition) are demonstrated to make photosensitive $p-n$ heterojunction diodes.

\section{ACKNOWLEDGMENTS}

The authors would like to acknowledge a number of helpful discussion with Professor E. A. Schiff (Syracuse University). This work was funded by the National Science Foundation (Grant No. DMR-88-20779 and DDM92-2288), the International Society for Hybrid Microelectronics, and Syracuse University.

${ }^{1}$ A. F. Jankowski, L. R. Schrawyer, and M. A. Wall, J. Appl. Phys. 68, $5162(1990)$.

${ }^{2}$ A. F. Jankowski and P. L. Perry, Thin Solid Films 206, 365 (1991).

${ }^{3}$ K. Ploog, J. Cryst. Growth 24/25, 197 (1974).

${ }^{4}$ N. Fugimori, T. Imai, and A. Doi, Vacuum 36, 99 (1986).

${ }^{5}$ K. Okano, H. Naruki, Y. Akiba, T. Kurosu, M. Iida, and Y. Hirose, Jpn. J. Appl. Phys. 27, L173 (1988); K. Okano, Y. Akiba, T. Kurosu, M. Iida, and T. Nakamura, J. Cryst. Growth 99, 1192 (1990).

${ }^{6}$ Y.-G. Kim, P. A. Dowben, and J. T. Spencer, J. Vac. Sci. Technol. A 7, 2796 (1989).

${ }^{7}$ J. Mazurowski, S. Baral-Tosh, G. Ramseyer, J. T. Spencer, Y.-G. Kim, and P. A. Dowben, in Plasma Processing and Synthesis of Materials, MRS Symposium Proceedings, edited by D. Apelian and J. Szekely (MRS, Pittsburgh, PA, 1991), Vol. 190, p. 101; J. Mazurowski, S. Lee, G. Ramseyer, and P. A. Dowben, in Wide Band Gap Semiconductors, MRS Symposium Proceedings, edited by T. D. Moustakas, J. I. Pankove, and Y. Hamakawa (MRS, Pittsburgh, PA, 1992), Vol. 242, p. 637.

${ }^{8}$ F. K. Perkins, M. Onellion, S. Lee, D. Li, J. Mazurowski, and P. A. Dowben, Appl. Phys. A 54, 442 (1992).

${ }^{9} \mathrm{~K}$. A. Schwetz and P. Karduck, in Boron Rich Solids, AIP Conference Proceedings No. 231, edited by D. Emin, T. L. Aselage, A. C. Switendick, B. Morosin, and C. L. Beckel (AIP, New York, 1991), p. 405.

${ }^{10}$ D. L. Belitskus, R. J. Campbell, and S. Y. Tzeng, in Boron Rich Solids, AIP Conference Proceedings No. 231, edited by D. Emin, T. L. Ase- lage, A. C. Switendick, B. Morosin, and C. L. Beckel (AIP, New York, 1991), p. 481.

${ }^{11}$ A. W. Mullendore, in Boron Rich Solids, AIP Conference Proceedings No. 140, edited by D. Enin, T. Aselage, C. L. Beckel, I. A. Howard, and C. Wood (AIP, New York, 1986), p. 41.

${ }^{12} \mathrm{~F}$. Thevenot and M. Bougoin, in Boron Rich Solids, AIP Conference Proceedings No. 140, edited by D. Emin, T. Aselage, C. L. Beckel, I. A. Howard, and C. Wood (AIP, New York, 1986), p. 51.

${ }^{13}$ N. B. Elsner, G. H. Reynolds, J. H. Norman, and C. H. Sheaver, in Boron Rich Solids, AIP Conference Proceedings No. 140, edited by D. Emin, T. Aselage, C. L. Beckel, I. A. Howard, and C. Wood (AIP, New York, 1987), p. 59.

${ }^{14}$ T. L. Aselage, in Novel Refractory Semiconductors, MRS Symposium Proceedings, edited by D. Emin, T. L. Aselage, and C. Wood (MRS, Piltsburgh, PA, 1987), Vol. 97, p. 101.

${ }^{15}$ A. N. Campbell, A. W. Mullendore, D. R. Tallant, and C. Wood, in Novel Refractory Semiconductors, MRS Symposium Proceedings, edited by D. Emin, T. L. Aselage, and C. Wood (MRS, Pittsburgh, PA, 1987), Vol. 97, p. 113.

${ }^{16} \mathrm{~V}$. Cholet, R. Herbin, and L. Vandenbulke, Thin Solid Films 188, 143 (1990).

${ }^{17}$ M. Olsson, S. Sönderberg, B. Stridh, U. Jansson, and J. O. Carlsson, Thin Solid Films 172, 95 (1989).

${ }^{18}$ U. Jansson and J. O. Carlsson, Thin Solid Films 124, 101 (1985); J. Vac. Sci. Technol. A 6, 1733 (1988).

${ }^{19}$ M. Bouchacourt and F. Thevenot, J. Lcss-Common Met. 82, 227 (1981)

${ }^{20}$ K. Ploog, J. Less-Common Met. 31, 177 (1973); 35, 115 (1974); 35, 131 (1974).

${ }^{21}$ U. Jansson, J. O. Carlsson, and B. Stridh, J. Vac. Sci. Technol. A 5, 2823 (1987).

${ }^{22}$ K. Ploog and E. Amberger, J. Less-Common Met. 23, 23 (1971); K. Ploog, H. Smidt, E. Amberger, G. Will, and K. H. Kossobutzki, J. Less-Common Met. 31, 177 (1972).

${ }^{23} \mathrm{E}$. Amberger, M. Druminski, and K. Ploog, J. Less-Common Met. 23, 43 (1971).

${ }^{24}$ U. Jansson, J. O. Carlsson, B. Stridh, S. Sönderberg, and M. Olsson, Thin Solid Films 172, 81 (1989).

${ }^{25}$ L. Varidenbulke and G. Vuillard, J. Less-Common Met. 82, 49 (1981).

${ }^{26}$ L. Vandenbulke, R. Herbin, M. Batuson, and J. N. Barfawden, J. LessCommon Met. 80, 7 (1981).

${ }^{27}$ D. N. Kevill, T. S. Rissmann, D. Breve, and C. Wood, J. Cryst. Growth 74, 210 (1986).

${ }^{28}$ H. L. Yakel, Acta. Cryst. B 31, 1797 (1975).

${ }^{29} \mathrm{M}$. Bouchacourt and F. Thevenot, J. Less-Common Met. 82, 219 (1981).

${ }^{30}$ H. E. Robson, Ph.D. dissertation, University of Kansas (1959).

${ }^{31}$ S. Mierzejewska and T. Niemyski, J. Less-Common Met. 8, 368 (1965).

${ }^{32}$ C. Wood and D. Emin, Phys. Rev. B 29, 4582 (1984).

${ }^{33}$ V. Cholet, R. Herbin, and L. Vandenbulcke, Thin Solid Films 188, 143 (1990).

${ }^{34}$ F. K. Perkins, R. A. Rosenberg, S. Lee, and P. A. Dowben, J. Appl. Phys. 69, 4103 (1991).

${ }^{35}$ R. A. Rosenberg, F. K. Perkins, D. C. Mancini, G. IIarp, B. Tonner, S. Lee, and P. A. Dowben, Appl. Phys. Lett. 58, 607 (1991).

${ }^{36}$ R. A. Rosenberg, S. P. Frigo, S. Lee, and P. A. Dowben, J. Appl. Phys. 71, 4795 (1992).

${ }^{37}$ Ph. Avouris, I.-W. Lyo, F. Bozso, and E. Kaxiras, J. Vac. Sci. Technol. A 8, 3405 (1990); I.-W. Lyo, E. Kaxiras, and Ph. Avouris, Phys. Rev. Lett. 63, 1261 (1989); Ph. Avouris, J. Phys. Chem. 94, 2264 (1990); G. Dujardin, R. E. Walkup, and Ph. Avouris, Science 255, 1232 (1992).

${ }^{38}$ S. Komatsu and Y. Moriyoshi, J. Appl. Phys. 66, 466 (1986); 66, 1180 (1989).

${ }^{39} \mathrm{~K}$. Shirai, S. Ae, and S. Gondo, in Boron Rich Solids, AIP Conference Proceedings No. 231, edited by D. Emin, T. L. Aselage, A. C. Switendick, B. Morosin, and C. L. Beckel (AIP, New York, 1991), p. 336.

${ }^{40}$ L. J. Dimmey, H. Park, P. L. Jones, and F. H. Cocks, J. Electron. Mater. 10, 111 (1981); F. H. Cocks, P. L. Jones, and L. J. Dimmey, Appl. Phys. Lett. 36, 970 (1980).

${ }^{41}$ D. Li, Y.-N. Xu, and W. Y. Ching, Phys. Rev. B 45, 5895 (1992).

${ }^{42}$ F. Perrot, Phys. Rev. B 23, 2004 (1981).

${ }^{43}$ D. M. Bullett, J. Phys. C 15, 415 (1982).

${ }^{44}$ S. Lee, D. M. Bylander, and L. Kleinman, Phys. Rev. B 42, 1316 (1990). 
${ }^{45}$ D. M. Bylander, L. Kleinman, and S. Lee, Phys. Rev. B 42, 1394 (1990).

${ }^{46}$ C. Mailhiot, J. B. Grant, and A. K. McMahan, Phys. Rev. B 42, 9033 (1990).

${ }^{47}$ S. Lee, D. M. Bylander, S. W. Kim, and L. Kleinman, Phys. Rev. B 45, 3248 (1992).

${ }^{48}$ D. Tomanek, R. M. Wentcovitch, S. G. Louie, and M. L. Cohen, Phys. Rev. 337, 3134 (1988).

${ }^{49}$ D. M. Bylander and L. Kleinman, Phys. Rev. B 43, 1487 (1991).

${ }^{50}$ L. Kleiman, in Boron Rich Solids, AIP Conference Proceedings No. 231, edited by D. Emin, T. L. Aselage, A. C. Switendick, B. Morosin, and C. I . Beckel (AIP, New York, 1991), p. 13.

${ }^{51}$ D. W. Bullett, in Boron Rich Solids, AIP Conference Proceedings No. 231, edited by D. Emin, T. L. Aselage, A. C. Switendick, B. Morosin, and C. L. Beckel (AIP, New York, 1991), p. 21.

${ }^{52}$ M. F. Florence and C. L. Beckel, in Boron Rich Solids, AIP Conference Proceedings No. 231, edited by D. Emin, T. L. Aselage, A. C. Switendick, B. Morusin, and C. L. Beckel (AIP, New York, 1991), p. 37.

${ }^{53} \mathrm{G}$. Will and A. Kirfen, in Boron Rich Solids, AIP Conference Proceedings No. 140, edited by D. Emin, T. Aselage, C. L. Beckel, I. A. Howard, and C. Wood (AIP, New York, 1986), p. 87.

${ }^{54} \mathrm{D}$. W. Bullett, in Boron Rich Solids, AIP Conference Proceedings No. 140, edited by D. Emin, T. Aselage, C. L. Beckel, I. A. Howard, and C. Wood (AIP, New York, 1986), p. 249.

${ }^{55} \mathrm{~J}$. Tauc, in Optical Properties of Solids, edited by F. Abeles (North Holland, Amsterdam, 1972), p. 279.

${ }^{36}$ S. Lee, D. Li, P. A. Dowben, F. K. Perkins, M. Onellion, and J. T. Spencer, J. Am. Chem. Soc. 113, 8444 (1991).

${ }^{57}$ N. N. Greenwood and R. Greatrex, Pure Appl. Chem. 59, 857 (1987).

${ }^{58}$ H. H. Madden, G. C. Nelson, and W. O. Wallace, in Boron Rich Solids, AlP Conference Proceedings No. 140, edited by D. Emin, T. Aselage, C. L. Beckel, I. A. Howard, and C. Wood (AIP, New York, 1986), p. 121.

${ }^{59}$ O. A. Golikova, Sov. Phys. Solid State 29, 1652 (1987).

${ }^{60} \mathrm{H}$. Werheit, H. Binnenbruck, and A. Hausen, Phys. Status Solidi B 47, 153 (1971).

${ }^{61}$ L. Zuppiroli, N. Papandreou, and R. Kormann, J. Appl. Phys. 70, 246 (1991).

${ }^{62}$ O. A. Golikova, in Boron Rich Solids, AIP Conference Proceedings No. 231, edited by D. Emin, T. L. Aselage, A. C. Switendick, B. Morosin, and C. L. Beckel (AIP, New York, 1991), p. 108.

${ }^{63}$ D. Emin, in Novel Refractory Semiconductors, MRS Symposium Proceedings, edited by D. Emin, T. L. Aselage, and C. Wood (MRS, Pittsburgh, PA, 1987), Vol. 97, p. 3.

${ }^{64}$ D. Emin, in Boron Rich Solids, AIP Conference Proceedings No. 231, edited by D. Emin, T. L. Aselage, A. C. Switendick, B. Morosin, and C. L. Beckel (AIP, New York, 1991), p. 65.

${ }^{65}$ D. Emin, in Boron Rich Solids, AIP Conference Proceedings No. 231, edited by D. Emin, T. L. Aselage, A. C. Switendick, B. Morosin, and C. L. Beckel (AIP, New York, 1991), p. 65.

${ }^{66}$ G. A. Samara, H. L. Tardy, E. L. Vendurini, T. L. Aselage, and D. Emin, in Boron Rich Solids, AIP Conference Proceedings No. 231, edited by D. Emin, T. L. Aselage, A. C. Switendick, B. Morosin, and C. L. Beckel (AIP, New York, 1991), p. 77.

${ }^{67}$ D. Emin, in Boron Rich Solids, AIP Conference Proceedings No. 140, edited by D. Emin, T. Aselage, C. L. Beckel, I. A. Howard, and C. Wood (AIP, New York, 1986), p. 189.

${ }^{68}$ A. K. Bandyopadhyay, F. Beuneu, L. Zuppiroli, and M. Beauvy, J. Phys. Chem. Solids 45, 207 (1984).

${ }^{69}$ N. Papandreou and L. Zuppiroli, in Boron Rich Solids, AIP Conference Proceedings No. 231, edited by D. Emin, T. L. Aselage, A. C. Switendick, B. Morosin, and C. L. Beckel (AIP, New York, 1991), p. 85.

${ }^{70}$ A. N. Campbell, A. W. Mullendore, D. R. Tallant, and C. Wood, in Novel Refractory Semiconductors, MRS Symposium Proceedings, edited by D. Emin, T. L. Aselage, and C. Wood (MRS, Pittsburgh, PA, 1987), Vol. 97, p. 113.

${ }^{71}$ D. Geist, in Boron, Vol. 2, Preparation, Properties and Applications, International Symposium on Boron, edited by G. K. Gaule (Plenum, New York, 1965), p. 203.

${ }^{72}$ H. Werheit and K. deGroot, Phys. Status Solidi B 97, 229 (1980)

${ }^{73}$ H. Werheit, U. Kuhlmann, R. Franz, W. Winkelbauer, B. Herstell, D. Finster, and H. Neisius, in Boron Rich Solids, AIP Conference Proceedings No. 231, edited by D. Emin, T. L. Aselage, A. C. Switendick, B. Morosin, and C. L. Beckel (AIP, New York, 1991), p. 104.
${ }^{74}$ R. Uno, H. Ozawa, and J. Ishigaki, in Boron Rich Solids, AIP Conference Proceedings No. 231, edited by D. Emin, T. L. Aselage, A. C. Switendick, B. Morosin, and C. L. Beckel (AIP, New York, 1991), p. 130.

${ }^{75}$ D. Gosset, M. Gvery, and B. Kryger, in Boron Rich Solids, AIP Conference Proceedings No. 231, edited by D. Emin, T. L. Aselage, A. C. Switendick, B. Morosin, and C. L. Beckel (AIP, New York, 1991), p. 380.

${ }^{76}$ R. Kormann and L. Zuppiroli, in Boron Rich Solids, AIP Conference Proceedings No. 140, edited by D. Emin, T. Aselage, C. L. Beckel, I. A. Howard, and C. Wood (AIP, New York, 1986), p. 216.

${ }^{77}$ C. Wood, in Boron Rich Solids, AIP Conference Proceedings No. 140, edited by D. Emin, T. Aselage, C. L. Beckel, I. A. Howard, and C. Wood (AIP, New York, 1986), p. 206.

${ }^{78} \mathrm{H}$. Werheit and S. Rospendowski, in Boron Rich Solids, AIP Conference Proceedings No. 140, edited by D. Emin, T. Aselage, C. L. Beckel, I. A. Howard, and C. Wood (AIP, New York, 1986), p. 234.

${ }^{79} \mathrm{H}$. Werheit, in Boron Rich Solids, AIP Conference Proceedings No. 140, edited by D. Emin, T. Aselage, C. L. Beckel, I. A. Howard, and C. Wood (AIP, New York, 1986), p. 325.

${ }^{80}$ R. Franz, H. Werheit, and A. J. Nodolny, in Boron Rich Solids, AIP Conference Proceedings No. 140, edited by D. Emin, T. Aselage, C. L. Beckel, I. A. Howard, and C. Wood (AIP, New York, 1986), p. 340.

${ }^{81}$ P. R. H. Türkes, E. T. Swartz, and R. O. Pohl, in Boron Rich Solids, AIP Conference Proceedings No. 140, edited by D. Emin, T. Aselage, C. L. Beckel, I. A. Howard, and C. Wood (AIP, New York, 1986), p. 346.

${ }^{82}$ C. Wood, in Boron Rich Solids, AIP Conference Proceedings No. 140 , edited by D. Emin, T. Aselage, C. L. Beckel, I. A. Howard, and C. Wood (AIP, New York, 1986), p. 362.

${ }^{83}$ A. Szadkowski, J. Less-Common Met. 67, 551 (1979).

${ }^{84}$ A. J. Nadolny, J. Less-Common Met. 67, 125 (1979).

${ }^{85}$ N. Morita and A. Yamamoto, Jpn. J. Appl. Phys. 14, 825 (1975).

${ }^{86} \mathrm{~W}$. Neft and K. Seiler, in Boron, Vol. 2, Preparation, Properties and Applications, International Symposium on Boron, edited by $\mathbf{G}$. $\mathbf{K}$. Gaule (Plenum, New York, 1965), p. 143.

${ }^{87}$ T. Niemyski and W. Zawadzki, Phys. Lett. 2, 30 (1962).

${ }^{88} \mathrm{Sh}$. Z. Dzhamagidze, Yu. A. Mal'tsez, and R. R. Shvangiradze, Sov. Phys. Semicond. 2, 320 (1968).

${ }^{89}$ E. S. Greiner and J. A. Gutowski, J. Appl. Phys. 28, 1364 (1957).

${ }^{90}$ R. Uno, J. Phys. Soc. Jpn. 13, 667 (1958).

${ }^{91}$ C. Wood and M. Thurston, J. Electrochem. Soc. 109, 66 (1962).

${ }^{92}$ J. C. Thompson and W. J. McDonald, Phys. Rev. 132, 66 (1962).

${ }^{93}$ R. A. Brungs and V. P. Jacobsmeyer, J. Phys. Chem. Solids 25, 701 (1964).

${ }^{94}$ W. Borchert, W. Dietz, and H. Herrmann, Z. Angew, Phys. 19, 485 (1965).

${ }^{95}$ D. Geist and H. G. Claser, J. Phys. Chem. Solids 26, 57 (1965).

${ }^{96}$ A. Szadrowski, J. Less-Common Met. 67, 551 (1979).

${ }^{97}$ F. Horn, J. Appl. Phys. 30, 1611 (1959).

${ }^{98}$ G. D. Cody, B. Abeles, C. R. Wronski, B. Brooks, and W. A. Lanford, J. Non-Cryst. Solids 35/36, 463 (1980).

${ }^{99}$ W. Klein, J. Less-Common Met. 47, 101 (1976).

${ }^{100}$ H. L. Tardy, T. L. Aselage, and D. Emin, in Boron Rich Solids, AIP Conference Proceedings No. 231, edited by D. Emin, T. L. Aselage, A. C. Switendick, B. Morosin, and C. L. Beckel (AIP, New York, 1991), p. 138.

${ }^{101} \mathrm{H}$. Werheit, U. Kuhlmann, F. H. Werheit, and G. Krach, in Boron Rich Solids, AIP Conference Proceedings No. 231, edited by D. Emin, T. L. Aselage, A. C. Switendick, B. Morosin, and C. L. Beckel (AIP, New York, 1991), p. 144.

${ }^{102}$ U. Kühlmann, H. Werheit, B. Fahy, and P. Perkins, in Boron Rich Solids, AIP Conference Proceedings No. 231, edited by D. Emin, T. L. Aselage, A. C. Switendick, B. Morosin, and C. L. Beckel (AIP, New York, 1991), p. 148.

${ }^{103}$ R. Franz and H. Werheit, in Boron Rich Solids, AIP Conference Proceedings No. 231, edited by D. Emin, T. L. Aselage, A. C. Switendick, B. Morosin, and C. L. Beckel (AIP, New York, 1991), p. 29.

${ }^{104}$ H. Werheit, U. Kuhlmann, N. E. Sobv'ev, G. P. Tsiskarishvili, and G. Tsagareishvili, in Boron Rich Solids, AIP Conference Proceedings No. 231, edited by D. Emin, T. L. Aselage, A. C. Switendick, B. Morosin, and C. L. Beckel (AIP, New York, 1991), p. 350.

${ }^{105}$ T. F. Deutch, J. C. C. Fan, G. W. Turner, R. L. Chapman, D. J. Ehrlich, and R. M. Osgood, Jr., Appl. Phys. Lett. 38, 144 (1981); B. 
S. Meyerson, F. K. Legoues, T. N. Tauyen, and D. L. Haranil, Appl. Phys. Lett. 50, 113 (1987); A. B. McLean, L. J. Terminello, and F. J. Himpsel, Phys. Rev. B 41, 7694 (1990).

${ }^{106}$ M. C. Tamargo, M. J. S. P. Brasil, R. E. Nahory, R. J. Martin, H. H. Farrell, T. J. Gmitter, D. E. Aspnes, A. L. Weaver, Y. Zhang, and B. J. Skromine, J. Vac. Sci. Tcchnol. B 10, 692 (1992).

${ }^{107}$ H. Shioni, Y. Nishibayashi, and N. Fujimori, Jpn. J. Appl. Phys. 29, L2163 (1990).
${ }^{108}$ J. P. Long, H. R. Sadeghi, J. C. Rife, and M. N. Kabler, Phys. Rev. Lett. 64, 1158 (1990).

${ }^{109} \mathrm{~J}$. A. Shelnutt, B. Morosin, D. Emin, A. Mullendore, G. Slack, and C. Wood, in Boron Rich Solids, AIP Conference Proceedings No. 140, edited by D. Emin, T. Aselage, C. L. Beckel, I. A. Howard, and C. Wood (AIP, New York, 1986), p. 312.

${ }^{110}$ T. M. Ducan, in Boron Rich Solids, AIP Conference Proceedings No. 140, edited by D. Emin, T. Aselage, C. L. Beckel, I. A. Howard, and C. Wood (AIP, New York, 1986), p. 177. 